\section{Penicillin-induced Granulopenia}

SIR,-I have read with interest the article by Dr. J. M. White and his colleagues (6 July, p. 26), in which they presented the case histories of two patients with penicillininduced haemolytic anaemia, and in one of whom there was also a moderate leucopenia. I have studied the case histories of 13 other patients with penicillin-induced haemolytic anaemia which have been reported in the literature, and I find that the white cell count was recorded in only three, and in one of these there was a severe granulopenia. ${ }^{1}$ Penicillin $G$ is not listed by Wintrobe $e^{2}$ as a drug which has been recorded as causing leucopenia. It seems, therefore, that penicillin $G$ has been observed to produce leuconenia only in association with haemolytic anaemia, and this prompts me to describe the case history of a patient in whom there was strong circumstantial evidence that penicillin $G$ produced a severe granulopenia but not haemolytic anaemia.

The patient, a man aged 47 , had been told that he had a cardiac valvular lesion when he was at school, but this had never caused any symptoms. He was admitted to Sefton General Hospital with a history of tiredness, loss of weight, and generalized aches and pains for six months. On examination he was found to have a temperature of $101^{\circ} \mathrm{F} .\left(38.3^{\circ} \mathrm{C}\right.$.), signs of aortic stenosis and incompetence, purpura on the legs, and splenomegaly. The haemoglobin was $9.8 \mathrm{~g} .100 \mathrm{ml}$., white cell count $8,300 / \mathrm{cu}$. mm. and E.S.R. $68 \mathrm{~mm}$./hour. The red blood cells were normochromic and slightly microcytic and showed increased polychromasia. Eleven blood cultures were negative, lupus erythematosus cells were not found, and the serum antinuclear factor was negative. The urine contained a moderate number of red blood cells.

In view of the clinical features, it was decided that probably he had infective endocarditis, and treatment was started with penicillin G 8 mega units a day, and probenecid $0.5 \mathrm{~g}$. six-hourly. Four days later streptomycin 2 g. a day was added. On the ninth day of treatment the white cell count had fallen to $5,150 / \mathrm{cu}$. mm., and seven days later it was only $2,700 / \mathrm{cu}$. $\mathrm{mm}$. with a normal differential count. The streptomycin and probenecid were stopped, and the penicillin $G$ increased to 16 mega units intravenously daily for five days and then to 32 mega units intravenously daily. After six days on the latter dose of penicillin the white cell count had fallen to $1,050 / \mathrm{cu}$. mm. (polymorphs $9 \%$, lymphocytes $88 \%$, monocytes $2 \%$, eosinophils $1 \%$ ) The haemoglobin was still $9.8 \mathrm{~g} .1100 \mathrm{ml}$., and the blood film showed increased polychromasia of the red cells. The reticulocytes were $2 \%$, platelets $187,000 / \mathrm{cu}$. mm., and the direct Coombs test was negative. Penicillin therapy was continued for a further week, during which time the white cell count varied between 950 and $1,500 / \mathrm{cu}$. mm. and the polymorphs fell to $2 \%$ of the total count. Bone marrow aspiration at that time produced a cellular sample which contained plenty of normoblasts, megakaryocytes, and myelocytes but no mature granulocytes. The direct Coombs test remained negative.

Penicillin was then replaced by erythromycin $0.5 \mathrm{~g}$. six-hourly, and within two days the white cell count had risen to $2,500 / \mathrm{cu}$. mm. (poly morphs $16 \%$, lymphocytes $67 \%$, monocytes $17 \%$ ). The white cell count improved daily and there was a transient appearance of a few myelocytes in the peripheral blood. Two weeks later the white cell count was 10,600/cu. mm. (polymorphs $73 \%$, lymphocytes $19 \%$, monocytes $8 \%$ ). Erythromycin was continued for two months, the white cells remained norma and the haemoglobin level rose to $13.0 \mathrm{~g} . / 100$ $\mathrm{ml}$. Subsequently the severity of the aortic incompetence rapidly increased and he died in congestive cardiac failure. Necropsy revealed vegetations on a calcified aortic valve, and one of the cusps had been torn away from the valve ring.

The presence of normal numbers of immature myeloid cells in the bone marrow suggests that the penicillin was not impairing granulopoiesis but causing the destruction of the mature granulocytes, presumably by a similar mechanism to that which produces haemolysis. It is difficult to understand, however, why the granulocytes and not the red cells should be coated with penicillin Whatever the actual mechanism involved there seems no doubt that penicillin $G$ was the cause of the granulopenia, and the practical lesson to be drawn from this case is that penicillin therapy should be promptly stopped in these circumstances. - I am, etc. \section{Sefton General Hospital
Liverpool 15.}

\section{J. Forshaw.}

\section{REFERENCES}

1 Petz, L. D., and Fudenberg, H. H., New Engl. 7. Med., 1966, 274, 171 Hematology, 1968, 6t

\section{Helicopters and Medical Emergencies}

SIR,-Your leading article on helicopter services (29 June, p. 778) is welcome. It points out the necessity for this service, as does the present compromise with armed Forces, if only this were more widely known. Compromise, and dangerous compromise, is what it is.

Your leader is written in restrained language. For instance, the phrase "... conveyance by air of patients for whom the delay or the disturbance of a long journey by road is considered undesirable" covers such ordeals as travelling in a jolting roadwagon on substandard roads for up to 150 miles $(240 \mathrm{~km}$.) with a perforated viscus, a coronary thrombosis, or grave internal bleeding. This restraint of speech could be misinterpreted, as for example when it is stated that such medical helicopter flights can be arranged " at leisure, rather than as emergencies." In winter, in Northern Scotland, there is little "leisure" left after one has travelled whatever distance, by land or sea, and found a patient requiring urgent removal. It is a race against imminent night and limiting weather conditions. The idea of having this ambulance available " on request by medical officers of health" is barbarous. Some of us still remember the Princess Victoria disaster, and the contribution to it of an unjustifiably long chain of communication to the rescue services. The helicopter should be directly available to the doctor in the field, who has the fullest knowledge of the circumstances, and who holds his job for his knowledge of transport as well as medicine. The machines, few if you will, must be deployed where they are to be required; and in Scotland this means west of the watershed. Cost is phony. What is expense to the "user" is revenue to the " owner," both of whom are at most public, and at best would be the one authority.

There is a national, social implication. At present, in remote (and very attractive) communities friends see the departure by road of some friend to hospital. They have to wait many anxious hours to hear if the patient has reached there alive. The thought arises in their minds, "Why do we stay here ?" And so they start going in order to save themselves or their children from that journey. This service would help to prevent communities which are at present an asse from becoming, first a liability, and then just a memory.-I $2 \mathrm{~m}$, etc.

$$
\begin{aligned}
& \text { North Uist, } \\
& \text { Inverness-shire. }
\end{aligned}
$$

\section{Toxicology of Silicones}

SIR,-Based on the histology of biopsy material taken from two cases of foreign body mastitis and on hearsay that the material injected was silicone, Professor W. St. C. Symmers says, "it seems to be clear that these substances [the silicones] are neither biologically inert nor harmless." This statement, like the topless waitresses, is completely unsupported. The toxicology of silicones has been investigated very thoroughly ${ }^{1-8}$ and its medical uses are now legion. To my knowledge there are over 400 publications on this subject.

My interest is in orthopaedics, where there are many applications for the silicone oils and rubbers, and these have proved extremely valuable in clinical use. I approached the use of this material with considerable caution After examining all the published reports, together with Dr. M. Brookes at Guy's Hospital, animal experiments were performed to assess the biological effects of silicone oil both locally and systemically. The conclusion was that the sole hazard lay in the embolic effects that would result if the oil were introduced directly into a vessel. We learnt that the silicones are very easily contaminated, so that sterilization and handling techniques must be beyond reproach. Pure silicone oil is so non-reactive that it drifts in subcutaneous fat. This has proved a problem for those using the oil for breast augmentation, and so organic oils have been deliberateiy added to try and promote an inflammatory reaction which would localize the injected silicone (Japanese Sakurai formula). ${ }^{4}$ I suspect that this may have been the material used in the two patients described in Professor Symmers's paper.

I have used silicone oil as an artificial lubricant for arthritic joints in over 200 patients during the past three years. No complications have been encountered and there have been no local or systemic ill effects. The first 15 patients so treated were carefully monitored. Complete blood tests and function tests of central nervous, cardiovascular, renal, and hepatic systems were carried out before treatment and subsequently at threemonthly intervals for a year and thereafter biannually, with negative results. Histological material has been obtained from joints which have contained silicone oil for up to $2 \frac{1}{2}$ years, and no abnormality, apart from a mild lymphocyte response, has been noted. The silicones have been clinically used for almost 20 years. In none of the animal work has there been any evidence of carcinoma formation as a result of the silicone oil introduced. Incidences reported ${ }^{2}$ were later proved to be unrelated to the silicone. ${ }^{3}$ No neoplasm formation has ever been recorded in humans. 
I personally deplore the practice of breast augmentation by injection of foreign material with its attendant risk of masking the appearance of a carcinoma ; this, however, is not a valid reason for condemning the silicones, which, if properly used in pure form and carefully handled to avoid contamination, are extraordinarily inert and may prove to be the most useful and safest of the implant materials we have at our disposal.-I am, eic.,

London $\mathbb{W} .1$

\section{B. Helal.}

REFERENCES

4 Ashley, F. L., Braley, S., Rees, T. D., Goulian, D., and Ballantyne, D. L., Plast. Reconstr.

= Ben-Hur, 1967, 39, 411. ., and Neuman, Z., Israel med. 7., 1963, 22, is.

Grasso, P., Goiberg, L., and Fairweather, F. A.. Lancet, 1964, 2, 96.

Kagan, H. D., Arch. Otolaryng. 1963, 78, 663. Little, K., and Parkhouse, J., Lancet, 1962, 2. Rees, T. D., Platt, J., and Ballantyne,

Plast. Reconstr. Surg.
Rowe, V. K., Spencer, H. C., 35, 131.
Bass, S. L.,

- F. industr.' Hyg. 1948, $30,332$. Rowe, V. K., Spencer, H. C., and Bass, S. L.,
Arch. industr. Hyg., 1950, 1, 539 .

\section{E.E.G. Signs of Death}

SIR,-Following your leading article on this subject (1t May, p. 318) I wrote (1 June, p. 557) adding some points relevant to our present study of the borderland between life and death and quoted some additional literature contains little information about joint considered these quotations to consist "largely of anecdote or of opinion published in society proceedings." May I point out that the work of the French authors I quoted ${ }^{1-4}$ is highly respected by whoever is reasonably familiar with the study of E.E.G. in the borderland between life and death. We still have a great deal to learn from many sources, in many languages, as to how the brain works in health and disease.

As to my proposals for the creation of a mobile E.E.G. unit to study resuscitated patients in various hospitals, constructive remarks will be welcome. However, Dr. Binnie's comments as to the quality of the work of such a unit "offering ill-founded and largely speculative opinions in the middle of the night" are not based on facts, as such a unit does not yet exist. A third point to which serious thought should be given is what Dr. Binnie calls "the E.E.G. diagnosis of death." E.E.G. may offer fundamental information about either recoverable or non-recoverable cerebral function, while the patient may be kept alive by various means. How can E.E.G. be expected "to diagnose death" ?-I am, etc.,

Hospital for Sick Children,

\section{G. Pampiglione.}

London W.C.1.

\section{REFERENCES} Wertheimer, P., Jouvet, M., and Descartes, J.,
Presse méd.,'1959, 67, 87.

Fischgold, H., and Mathis, P., Electroenceph. clin. Neurophysiol., 1959, Suppl. 11.

- Arfel, G., and Fischgold, H., Electraenceph. clin. Neurophysiol., 1961, 13, 653 .

- Vigouroux, R. P., Marseille chir., 1966, 18, 6.

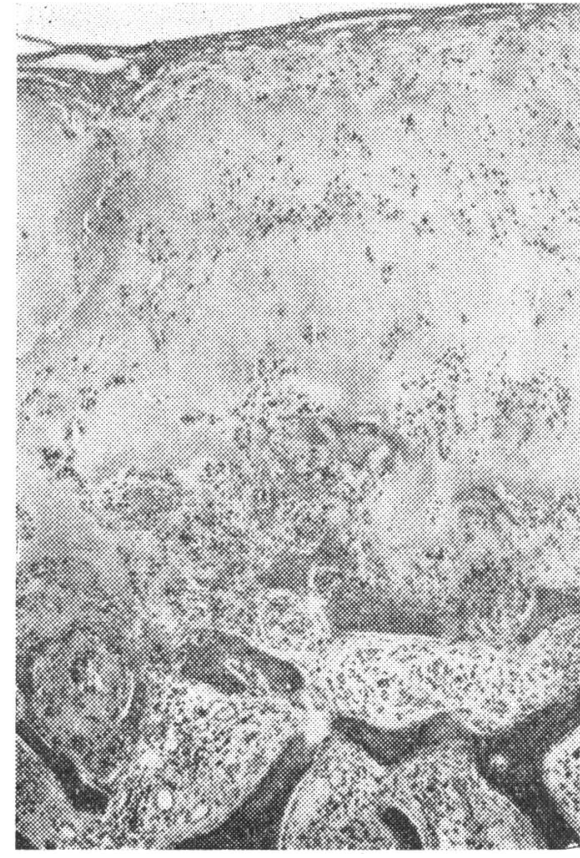

FIG. 2

tion of the process occurring in rheumatoid arthritis differs importantly from that based on earlier studies in which conclusions were drawn from cases with advanced destructive disease.-I am, etc.,

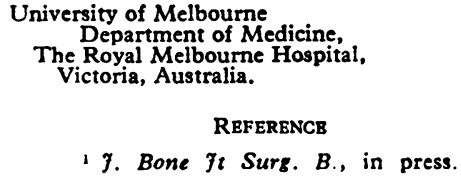

REFERENCE

1 f. Bone $f_{t}$ Surg. B., in press.

\section{Anaemia and Hiatus Hernia}

SIR,-I was very interested to read the article concerning iron absorption and daily blood loss in patients suffering from anaemia as a complication of hiatus hernia (6 July, p. 22). I enjoyed this article but wish to disagree with the authors' conclusions in the last paragraph.

Patients with sliding hernia occasionally present with large haematemeses sufficient to endanger their lives, and oral iron will hardly deal with this emergency. Although continuous oral iron may well keep the anaemia under control, nevertheless the hernia is still present and therefore the other major complications of spill-over pneumonitis and stricture are still liable to occur. Also there is some evidence to show that the incidence of carcinoma of the lower oesophagus may be slightly higher in patients with a sliding hernia than in those without this condition.

I believe that the complications of hiatus hernia, of which anaemia is only one, are potentially so serious that all patients with this condition should be considered for surgical repair, and if this repair is carried out through a lower thoracotomy then the morbidity and mortality rate of the operation is negligible.-I am, etc.,

Michael Bates.

Department of Thoracic Surgery,

North Middlesex Hospital,
London N.18. 